women shehas interviewed in Toronto are generally better able and equipped to restructure (re-invent themselves as bicultural-bilingual) new selves as compared to Latin American men. While women are able to establish a continuity of tasks related to their past lives in Latin America, as well as to secure new and meaningful tasks in the Canadian context, men's core identity/masculinity is challenged by the refugee ordeal. Men experience severe losses due to changes in their work status, and in effective parental and financial-provider roles. In effect, Freire's research demonstrates that traditional Latin American gender relations can contribute to women's empowerment and men's disempowerment in the new country of resettlement.

All of these papers challenge the traditional view of refugee women as solely and always passive "victims," and demonstrate the need to give "voice" to women as well as the ways in which women have proactively taken "voice." They describe a feminist approach to refugee issues that is based on a more interactive relationship between refugee women and "others" than traditional, paternalistic approaches.

The preparation of this issue was carried out with Andrea Love, whose insight and skills were an invaluable part of the entire process of selection and editing. Finally, while a special issue on the gender relations of refugee migration is important, so is the mainstreaming of research on gender. Since gender relations involve both men and women, we hope to see more papers that address gender relations in every issue of this journal and encourage your submissions.

Wenona Giles, Guest Editor.

Professor Wenona Giles teaches in the Social Science Department of Atkinson College, York University, and is the coordinator of the Gender Unit at CRS

Andrea Love is a M.A. student in philosophy at York University and a research assistant at CRS.

\title{
The Canadian Guidelines On Women Refugee Claimants Fearing Gender-Related Persecution ${ }^{1}$
}

\author{
Judith Ramirez
}

\section{Introduction}

The vast majority of refugee claimants who reach the borders of industrialized countries are men, even though 80 percent of refugees worldwide are women. ${ }^{2}$ This fact alone would indicate the need to ensure that our determination systems are equipped to recognize forms of persecution suffered primarily, if not exclusively, by women. Otherwise, we perpetuate a system which doubly disadvantages women refugees. First, their lesser mobility and fewer resources limit their access to countries like the United States and Canada. And second, once they arrive (in disproportionately low numbers), their experiences of persecution and lack of state protection are less readily recognized.

There is a growing awareness that women often fear persecution for different reasons than men. Even when their fear has the same basis as men'srace, religion, nationality, political opinion, and membership in a particular social group-women often experience persecution differently. This has led the international community to begin to re-interpret the meaning of persecution, a concept which developed primarily in response to the experience of male refugees. ${ }^{3}$

In 1985, the Executive Committee of the United Nations High Commissioner for Refugees (UNHCR) recognized that women who face harsh or inhumane treatment for transgressing the social mores of their societies may be considered a "particular social group" within the UN definition of a Convention Refugee (UNHCR 1985). The UNHCR has also issued "Guide-

Judith Ramirez is an Immigration and Refugee Board member in Toronto, Canada, and a cochairperson of the Working Group on Women Refugee Claimants, IRB Toronto-I Unit. lines on the Protection of Refugee Women" (UNHCR 1991), and in 1993 the UN Commission on Human Rights adopted a resolution acknowledging that women are susceptible to particular sorts of human rights abuses.

\section{Development of the Gender Guidelines}

The Immigration and Refugee Board (IRB) ${ }^{4}$ Chairperson, Nurjehan Mawani, issued Guidelines on Women Refugee Claimants Fearing Gender-Related Persecution on March 9, 1993. The purpose of the Guidelines is to provide substantive legal and procedural guidance in analysing gender-related issues in refugee claims submitted by women. The legislative authority to issue the guidelines was given to the IRB Chairperson when amendments to the Immigration Act were enacted in February 1993. Canada is the first refugee-receiving country to establish formal guidelines for the adjudication of refugee claims made by women. ${ }^{5}$ The Guidelines now serve as the model for countries considering similar initiatives, including the United States and Australia.

The Guidelines are the culmination of a long process of vigorous discussion within the IRB. In 1990, the first Working Group on Women Refugee Claimants was established in Toronto. Co-chaired by Flora Liebich and myself, and the Group's principal objective was to train all the key participants in the determination process to deal with gender-based refugee claims. To that end, we organized a number of professional development workshops featuring a wide range of speakers, including UNHCR specialized staff, legal and human rights experts, medical practitioners assisting torture victims, and refugee women themselves.

The workshops addressed issues such as gender-based patterns of per-

Refuge, Vol. 14, No. 7 (December 1994)

(C) Authors, 1994. This open-access work is licensed under a Creative Commons Attribution-NonCommercial 4.0 International License, which permits use, reproduction and distribution in any medium for non-commercial purposes, provided the original author(s) are credited and the original publication in Refuge: Canada's Journal on Refugees is cited. 
secution experienced by women; the socialization process involving women from refugee-producing regions of the world; the impact of crosscultural misunderstanding on the assessment of a claimant's credibility; the use of the Convention ground of membership in a particular social group in gender-specific refugee claims; and the impact of international human rights instruments on genderbased claims.

In 1991, the Working Group held discussions with researchers in the IRB Hearings Branch about the need for a "preferred position paper" on gender part of public discourse. Our leading newspapers have reporters who specialize in the field, and it is not uncommon to see front-page articles and editorials on the subject. The voice of nongovernmental organizations is routinely reported and it is the commitment of these organizations to key issues that often serves as the engine for public debate. Chairperson Mawani later constituted a permanent consultative committee of IRB stakeholders and it met for the first time in February 1994. In addition, she has appointed a special advisor who is also the National Co-ordinator on Gender

\section{Similarly, a woman who chooses not to follow the precepts of a state religion or who does not fulfil the specific role assigned to women by religious doctrine, and is punished by the state as a result, may have a well-founded fear of persecution for reasons of religion.}

issues, a precursor to the Guidelines. In the following months, we responded to several early drafts. This was followed by a process of internal consultation across the country that was set in motion in March, 1992 at a Toronto workshop sponsored by the Working Group and the UNHCR. The IRB Legal Services became actively involved in canvassing relevant case law and scholarly commentary, and in drafting successive versions of the paper. The final phase consisted of external consultation with a wide range of organizations, including the Canadian Council for Refugees, UNHCR, Canadian Advisory Council on the Status of Women, Status of Women Canada, and the Canadian Council of Churches. From the numerous responses received by the Board, it was evident that our stakeholders viewed the Guidelines as an important initiative.

The public debate on a number of IRB decisions relating to women (Dench 1994) gave added impetus both to our internal deliberations on gender issues and to the sustained process of external consultations. In Canada, government policy on immigration and refugee matters is an entrenched
Issues and, Working Groups on Women Refugee Claimants have been set up at IRB centres across Canada.

Further administrative changes have been introduced that facilitate the tracking of gender-based claims before a hearing is scheduled. Working Group members are routinely assigned to hear gender-based claims. Refugee Hearings Officers (who act as counsel to the Board) liaise with claimants and their counsel to determine if there are issues of a particularly sensitive nature, such as sexual assault. If requested, every effort is made to provide a female panel as well as a female interpreter and Refugee Hearing Officer.

The use of expert witnesses is encouraged by the Board and, where circumstances warrant it, a claimant may give evidence through a statutory declaration or on video rather than through viva voce testimony.

\section{Overview of the Guidelines}

The Guidelines make several important points that reflect key issues in any gender-based analysis (Liebich and Ramirez 1993). The existing body of jurisprudence on the meaning of per- secution is primarily based on the experience of men. Aside from some cases of rape, the Convention definition has not been widely applied to such women's experiences as female infanticide, genital mutilation, brideburning, forced marriage, forced abortion, compulsory sterilization, or domestic violence.

The fact that certain forms of harm experienced by women, such as sexual and domestic violence, are universal, is irrelevant when determining whether these gender-specific crimes constitute forms of persecution. Just like religion, race, nationality, and political opinion, a gender-based "particular social group" may encompass large numbers of similarly-situated persons.

The Guidelines outline common forms of persecution directed primarily against women:

- persecution on the basis of kinship, where a political opinion is imputed to them due to the political views or activities of family members;

- severe discrimination based on the fact that they are women;

- persecution for transgressing against religious precepts, social mores, and legal or cultural norms; and

- exposure to violence by the authorities or private actors, including domestic violence, from which the state is unable or unwilling to protect them.

The "Framework of Analysis," which accompanies the Guidelines, is an important tool in analysing the link between gender, the feared persecution, and one or more of the grounds in the definition of a Convention refugee. The "Framework" includes an assessment of the following factors:

- the particular circumstances that give rise to the claimant's fear of persecution;

- the general conditions in the claimant's country of origin, including the nature of oppressive laws imposed upon women;

- the seriousness of the treatment feared by the claimant; 
- whether or not the claimant's fear of persecution is based on one or more of the grounds in the Convention Refugee definition;

- whether there is adequate state protection available to the claimant; and

- whether the claimant's fear of persecution is well-founded under all of these circumstances.

The Guidelines also point out that claims made by women which fall under the enumerated grounds of race, religion, nationality, or political opinion, may also require a gender-based analysis. For example, a woman who opposes institutionalized discrimination of women, or expresses views of independence from the male social/ cultural dominance in her society, may be found to fear persecution for reasons of imputed political opinion (i.e. she is perceived by the established political/social structure as expressing politically antagonistic views) (IRB 1993, 4).

Similarly, a woman who chooses not to follow the precepts of a state religion or who does not fulfil the specific role assigned to women by religious doctrine, and is punished by the state as a result, may have a wellfounded fear of persecution for reasons of religion. In the context of the Convention Refugee definition, the notion of religion should allow the freedom to hold or not to hold certain beliefs and the right to practice or not to practice the religion of one's choice (Ibid.).

It is important to note that, according to the Guidelines, a woman's refugee claim cannot be based solely on the fact that she objects to a national policy or law to which she is subject. She would need to establish that:

a) the policy or law is inherently persecutory; or

b) the policy or law is used as a means of persecution for one of the enumerated reasons; or

c) the policy or law, although having legitimate goals, is administered through persecutory means; or

d) the penalty for noncompliance with the policy or law is disproportionately severe (Ibid. 8).

\section{The Public/Private Dichotomy}

The Guidelines explicitly address the public/private distinction that has historically rendered women's experience invisible and prevented the recognition of women's societal rights as human rights, deserving of national and international protection. Canadian refugee jurisprudence has long recognized that violations of fundamental rights by non-state actors can form a basis for a refugee claim. ${ }^{6}$ The Guidelines apply this idea to severe discrimination on grounds of gender or acts of gendered violence, "either by public authorities or at the hands of private citizens from whose actions the state is unwilling or unable to adequately protect the concerned persons." 7 Thus, domestic and sexual violence (actual or threatened) by private citizens (i.e., husbands or boyfriends not susceptible to state control) can found a refugee claim. The critical issue is the availability of state protection. The Guidelines state:

Decision-makers should consider evidence indicating a failure of state protection in that governing institutions and/or their agents in the claimant's country of origin may have condoned the instances of sexual violence if they had been aware of them or did nothing to prevent them (IRB 1993, 8).

Since the advent of the Canadian Charter of Rights and Freedoms, jurisprudence on women's rights has challenged the public/private dichotomy in cases involving domestic and sexual violence by a male spouse. In $R$. v. Lavallee, ${ }^{8}$ the Supreme Court of Canada took issue with the prevailing societal pattern of accepting domestic violence. The view that the home is a private sphere within which the husband has unfettered control over his wife was directly challenged. Madam Justice Wilson said for the Court that "no man has a right to abuse any woman under any circumstances." According to leading feminist lawyer Mary Eberts, "[t]his is a real breakthrough, not only putting women at the centre of judicial analysis of cases involving women, but also in expressing severe social opprobrium of what had long been tolerated" (Eberts 1993, 8).

Similarly, in McGraw v. The Queen, ${ }^{9}$ the Supreme Court addressed the question of whether the threat of rape could be seen as a threat of grievous bodily harm. In his reasons, Mr. Justice Cory concluded that, "for women, rape under any circumstances must constitute a profound interference with their physical integrity. ${ }^{10} \mathrm{He}$ referred to unwanted sexual intercourse as "the ultimate violation of personal privacy," citing with approval the literature on the "rape trauma syndrome."11

\section{Cultural Relativism}

A critical issue in the international discourse on women's human rights is the universality of human rights versus "cultural relativism." In issuing the Guidelines, IRB Chairperson Mawani noted that, for Canada, "[t]his is not a matter of imposing western standards on other countries. It is a matter of respecting internationally accepted human rights standards" (IRB 1993). The 1948 Universal Declaration of Human Rights (UDHR) defines the basic principle of international human rights as "the inherent dignity and the equal and inalienable rights of all members of the human family [as] the foundation of freedom, justice and peace in the world."

According to Ed Broadbent, President of the International Centre for Human Rights and Democratic Development, based in Montreal, "the universality of human rights derives from the notion that all human beings are fundamentally equal in principle, and that neither culture, nor gender, nor race can detract from the entitlement of all people to the rights needed to uphold that dignity" (Broadbent 1994, 2). Mr. Broadbent states that "today universality is evolving, becoming more inclusive of historically marginalized populations. The principles of universal human rights are finally being applied to the protection-at least in theory-of the rights of women" (ibid. at 3). 
The Final Declaration, issued by the World Conference on Human Rights in Vienna in June 1994, mandated governments not only to protect but also to promote universal human rights:

All human rights are universal, indivisible, interdependent and inter-related. The international community must treat human rights globally in a fair and equal manner, on the same footing, and with the same emphasis. While the significance of national and regional particularities and various historical, cultural and religious backgrounds must be kept in mind, it is the duty of states, regardless of their political, economic and cultural systems to promote and protect all human rights and fundamental freedoms (Broadbent 1994, 5).

The Organization of African Unity's Convention Governing the Specific Aspects of Refugee Problems in Africa of September 10, 1969, regards the granting of asylum to refugees as a peaceful and humanitarian act that shall not be regarded as an unfriendly act by any member state. As well, the United Nations Convention on Territorial Asylum signed in Caracas on March 28, 1954, affirms that every state has the right to admit into its territory any person it wishes without giving rise to a complaint by any other member state. These measurers recognize that the role of the recipient countries is an essentially passive one-they admit those who arrive at their borders asking for protection under international human rights provisions.

Consistent with this approach, the Guidelines point to the use of international human rights instruments in adjudicating gender-based refugee claims:

The social, cultural, traditional and religious norms and the laws affecting women in the claimant's country of origin ought to be assessed by reference to human rights instruments which provide a framework of international standards for recognizing the protection needs of women. What constitutes permissible conduct by a state towards women may be determined, therefore, by reference to international instruments such as:
Universal Declaration of Human Rights; International Covenant on Civil and Political Rights; International Covenant on Economic, Social and Cultural Rights; Convention on the Elimination of All Forms of Discrimination Against Women; Convention on the Political Rights of Women; Convention on the Nationality of Married Women (IRB 1993, 7).

It is interesting to note that when the Guidelines were first issued, one of the criticisms levelled at the IRB was that inordinately large numbers of women would arrive on Canada's doorstep claiming refugee status. In fact, there has been little change in the number of claims made by women since the Guidelines were introduced. As mentioned earlier, although the overwhelming majority of the world's refugees are women, women lack the resources and mobility to travel to countries like Canada.

\section{Post-Guidelines Jurisprudence}

In the sixteen months since the Guidelines were issued, the IRB has been monitoring their implementation in the hearing room. A number of decisions illustrate the effect of the Guidelines on refugee claims made by women. ${ }^{12}$

Since the Guidelines were issued, the Supreme Court of Canada has handed down its landmark decision in Canada (Attorney General) v. Ward, ${ }^{13}$ which, along with other recent decisions of the Federal Court of Canada, elaborates on the interpretation of "membership in a particular social group." The Ward case outlines three categories that would constitute a "particular social group," one of which defines the group by "an innate or unchangeable characteristic." This category "would embrace individuals fearing persecution on such bases as gender, linguistic background, and sexual orientation."

Significantly, the Ward case also recognizes that "underlying the Convention is the international community's commitment to the assurance of basic human rights without discrimination."
As well, the Federal Court of Canada (Trial Division) has recently handed down its first decision which refers directly to the Guidelines. In the Mohamed decision of February 14, 1994, the Court ruled that if gender-related persecution is dealt with implicitly in the reasons, "this is not sufficient to discharge the obligation of the Board to provide clear reasons on all material issues raised by an applicant in support of a refugee claim." Madam Justice McGillis added, "I am satisfied that the Board failed to deliver reasons in the case at bar which squarely addressed the issue of gender-related persecution and therefore committed an error of law." The case was referred back to the IRB for a redetermination before a different panel.

\section{Conclusion}

The Guidelines are currently being updated to reflect recent developments in the jurisprudence on gender-related persecution. The decisions of the IRB reviewing courts as well as the IRB's own case-law will inform the revision process. The IRB is confident that the steps Canada has taken to assess gender-related claims equitably can be successfully applied to determination systems in other countries. The same principles which underlie Canada's Guidelines are evident in the draft Guidelines for Women Asylum Seekers, presented by the Women Refugees Project at Harvard University to the Immigration and Naturalization Service in the United States.

In a recent address to the Carnegie Endowment for International Peace in Washington, D.C., Mawani said:

While I am gratified by our accomplishments for women refugee claimants, I am aware that there is still much to be done; I continue to be aware that respect for and an understanding of these rights need to be translated into the fair and sensitive treatment of the individual woman refugee claimant. This is the challenge for all of us as we continue in the quest of guaranteeing meaningful gender inclusiveness for refugee women throughout the world (Mawani 1994). 


\section{Notes}

1. This is a revised version of a paper presented at the XIII ${ }^{\text {th }}$ World Congress of Sociology, "Development, Democracy and Women's Rights" session, in Bielefeld, Germany on July 23, 1994.

2. While the number of refugee claims in industrial countries has risen from 100,000 in 1983 to 800,000 in 1992 , this represents only 4 percent of the worldwide refugee population. The brunt of refugee protection is not borne by the industrialized countries, but by the developing regions of the world.

3. No definition of persecution is provided in the 1951 Convention, or in the Immigration Act. In Canada, the IRB is bound by the relevant jurisprudence of higher courts. It is also guided by the UNHCR Handbook on Procedures and Criteria for Determining Refugee Status and the international human rights instruments.

4. IRB is the largest administrative tribunal in Canada, and its Convention Refugee Determination Division (CRDD) has more than 200 independent decision makers, or Members, throughout the country. Roughly 42 percent of IRB members are women, and a wide range of racial and ethnocultural backgrounds are represented. Refugee claims are usually heard in the presence of two IRB Members at an in-camera hearing. In most cases, when one member decides in favour of the claim, the claimant is granted refugee status.

5. Up to 30,000 decisions on refugee claimants are made each year, of which 30 percent involve women. The acceptance rate for women claimants has consistently been somewhat higher than the overall average. In 1992, the acceptance rate for women stood at 64 percent as compared to 60 percent overall. In 1993, the overall acceptance rate was 55 percent, while the rate for women claimants remained marginally higher.

6. Rajudeen v. M.E.I. (1984), 55 N.R. 129 (F.C.A.). This case involved a Tamil whom the Sri Lankan police failed to protect from Sinhalese thugs.

7. Ibid.

8. [1990] 1 S.C.R. 852. In this case, a battered wife was acquitted of murdering her common-law husband on the grounds that she had a reasonable apprehension of bodily harm and was entitled to defend herself.

9. [1991] 3 S.C.R. 72.

10. lbid. at $83-85$.

11. For information on the symptoms associated with the "rape trauma syndrome," see discussion on "Post-Traumatic Stress Disorder" in the Diagnostic and Statistical Manual of Mental Disorders (Third Edition-Revised), American Psychiatric Association, Washington D.C., 1987.
12. - In Toronto, a battered wife from Ecuador was found to be a Convention Refugee two days after the Guidelines were released. Her counsel presented evidence that, in Ecuador, "violence is prohibited by law but is common in practice." In its analysis, the panel found that the unwillingness of the state to protect "Ecuadorian women subject to wife abuse may amount to persecution depending on the gravity of such abuse." (CRDD U92-08714 4/6/93)

- A Vancouver panel found that two Mayan sisters from Guatemala were refugees. The teenage girls were threatened with rape by soldiers because their father was involved with the guerrilla movement. As young women, they were particularly vulnerable in their society and they were not protected by the state authorities. (CRDD U92$00883 / 0088423 / 3 / 93$ )

- A battered wife from Jamaica was found not to be a refugee on the grounds that adequate protection from state authorities was available to her. Her testimony established that the police had responded repeatedly to her complaints and were prepared to charge her husband with assault. The police charged him on several occasions when other victims pressed charges. However, the claimant was unwilling to press charges. (CRDD T93-03535 30/7/83)

- A battered wife from Bulgaria was found to be a refugee when a Toronto panel concluded that state authorities had failed to protect her because her husband was employed by the security services. She complained to the police on several occasions and was told that no action would be taken against her husband because he had not violated public order. (CRDD T92-09592 14/9/93)

- In December 1993, a panel considered the case of a young Pakistani woman who was active in the student wing of the Pakistan People's Party. She had been physically and sexually assaulted by a man she recognized as belonging to a rival student political group. As a result of the attack, she became pregnant. Fearing that her father might have her killed to protect the family honour, she fled to Canada where she gave birth to her child. The panel decided the claimant had a well-founded fear of persecution because of her membership in the particular social group of raped, single females with a child born out of wedlock. The panel looked at the evidence showing that the penal laws in Pakistan weigh more heavily on women than on men. For a woman to prove sexual assault, she must obtain the confession of the perpetrator of the assault or the testimony of four adult male Muslim witnesses of the act. If a woman fails to prove the sexual assault, or does not file charges but becomes pregnant she is charged with adultery. The panel found that the claimant would face prejudicial treatment before the law, potential physical harm, and possible death if she were returned to Pakistan. (CRDD U9306372 10/12/93)

- A woman who fled Lebanon with her young son to avoid losing custody of him under Sharia law was recently admitted as a refugee. The panel examined the circumstances and concluded that her fundamental rights to equal treatment before the law would be violated because of her gender. Neither her rights as a parent nor the child's best interests would be considered in the custody proceedings under Sharia law. (CRDD T93-05935-36 31/12/ 93)

- In July 1994, a Toronto panel found a tenyear-old girl from Somalia to be a refugee on the grounds that she faces female genital mutilation - a violation of her fundamental right to personal security-if she returns to Somalia where this traditional practice is widespread. (CRDD T93-12198 $14 / 7 / 94)$

13. [1993] 2 S.C.R. 689.

\section{References}

Broadbent, E. 1994. "Cultural Relativism and Human Rights." Speech to the Immigration and Refugee Board International Women's Day Celebration, March 8. Montreal.

Dench, Janet. 1994. "Does Gender a Refugee Make?" Canadian Council for Refugees, Montréal. Unpublished paper.

Eberts, Mary. 1993. “Women's Equality Rights in Canadian Law." Unpublished speech, Immigration and Refugee Board International Women's Day Celebration, March 8. Toronto.

Immigration and Refugee Board. 1993. Guidelines on Women Refugee Claimants Fearing Gender-Related Persecution. Ottawa: IRB.

Immigration and Refugee Board. 1993. "News Release concerning Guidelines on Women Refugee Claimants Fearing Gender-Related Persecution, March 9. Ottawa: IRB.

Liebach, Flora and Judith Ramirez. 1993. "Gender Issues and Refugee Determination." Paper presented at the conference on Gender Issues and Refugees: Development Implications, May 9. Toronto: York University.

Mawani, Nurjehan. 1994. "Determining Gender-Related Claims to Refugee Status: The Canadian Perspective." Address to the Carnegie Endowment for International Peace, Washington D.C., April 19. Ottawa: IRB.

UNHCR. 1985. “Refugee Women and International Protection." Executive Committee, 36th session, 1985. Conclusion no. 39, 3.

UNHCR. 1991. “Guidelines on the Persecution of Refugee Women." Refugees, July 1991.

Refuge, Vol. 14, No. 7 (December 1994) 